\section{Postgraduate Agricultural Studentships}

A LIMrTED number of postgraduate studentships are to be awarded by the Ministry of Agriculture, Fisheries and Food and the Department of Agriculture and Fisheries for Scotland for the academic year beginning October 1 . The studentships are available in the various branches of husbandry, horticulture, farm management, agricultural or horticultural economics, agricultural or horticultural statistics, marketing, agricultural and dairy engineering (including farm mechanization and farm building), rural estate management and agricultural science. Applicants normally resident in England, Wales and Northern Ireland can obtain further information and forms of application from the Ministry of Agriculture, Fisheries and Food, Room 231A, Great Westminster House, Horseferry Road, London, S.W.1. Applicants normally resident in Scotland should apply to the Department of Agriculture and Fisheries for Scotland, Room 53, St. Andrew's House, Edinburgh, 1. The closing date for receipt of completed application forms is February 28. Awards are also available to postgraduate and post-doctoral students of agricultural science under the NATO Science Studentship and Fellowship Programme, which is intended to stimulate the exchange of students between member countries. The scheme is administered for United Kingdom students by the Science Research Council, State House, High Holborn, London, W.C.1, to which application should be made by March 1 .

\section{Medical Research Council: Industrial Psychology \\ Research Unit}

THE Industrial Psychology Research Unit of the Medical Research Council, which was formerly housed at University College, London, has now moved to the headquarters of the National Institute of Industrial Psychology, 14 Welbeck Street, London, W.1. Dr. C. B. Frisby, director of the Institute, will take over the honorary direction of the Unit from Prof. G. C. Drew. Aspects of the work of the Unit, which has been concerned with investigations of shift work, incentives, absenteeism, labour turnover and industrial accidents, will continue to appear in Occupational Psychology.

\section{University News:}

Birmingham

THe following appointments have been made: Dr. M. J. Chamberlain (lecturer in the Department of Experimental Pathology); Dr. G. Harris (Senior Research Fellow in the Department of Experimental Pathology); Dr. R. Jefferis (Research Fellow in the Department of Experimental Pathology).

\section{Edinburgh}

The following appointments have been made: Senior Lectureships, A. M. M. Wilson (bacteriology); Dr. A. D. S. Barr (mechanical engineering); Lectureships, R. A. Jones (animal health); Dr. J. Godfroy (zoology).

\section{London}

Dr. Lewis Wolpert, reader in zoology at King's College, has been appointed to the chair of Biology as applied to Medicine tenable at Middlesex Hospital Medical School. The title of professor of experimental pharma. cology has been conferred on Dr. J. R. Vane in respect of his post at the Institute of Basic Medical Sciences.

Newcastle upon Tyne

T. M. Frost has been appointed lecturer in the Department of Mechanical Engineering as from January 1.

\section{Sheffield}

Dr. R. J. MofretT has been appointed lecturer in applied mathematics.

\section{Announcements}

Mr. J. P. M. Brenan has been appointed deputy director of the Royal Botanic Gardens, Kew, and keeper of the herbarium and library, as from December 1, on the retirement of Dr. C. E. Hubbard.

THE Council of the Institute of Metals has made the following awards: Institute of Metals (Platinum) Medal for 1966, to Prof. F. A. Forward, Privy Council Office, Ottawa, for his services to the non-ferrous metal industries; Rosenhain Medal for 1966, to Mr. A. Cibula, British Non-ferrous Metals Research Association, for his contributions in the field of physical metallurgy.

Applications are invited from members of the Plastics Institute for the award of the Novadel Prize for 1965-66. The Prize, awarded annually by the Plastics Institute and worth 100 guineas, will be given for the best essay or report received before September 30, 1966, on some aspect of the reinforced plastics industry. Further information can be obtained from the Secretary, the Plastics Institute, 6 Mandeville Place, London, W.1.

A SEMINAR on "Planning and Organization of Science Research in Developing Countries", arranged by the Science of Science Foundation, will be held at the Ciba Foundation on March 14. Further information can be obtained from the Science of Science Foundation, c/o the Ciba Foundation, 41 Portland Place, London, W.1.

A symposium on "Non-elastic Processes in the Mantle", arranged by the Upper Mantle Committee of the International Union of Geodesy and Geophysics, will be held in the University of Newcastle upon Tyne, during February 21-25. Further information can be obtained from Dr. D. C. Tozer, School of Physics, University of Newcastle upon Tyne.

THE annual general meeting of the North of England Section of the Society for Analytical Chemistry will be held in Manchester on January 29. The meeting will be followed by the presentation and discussion of a paper entitled "Thermal Analysis with reference to Inorganic Hydrates". Furthor information can be obtained from the Society for Analytical Chemistry, 14 Belgrave Square, London, S.W.1.

A short course on "Recent Developments in Polymer Technology" will be held at the Bradford Institute of Technology during February 25-26. Lectures will include aspects of newer polymers; die design; polymer reinforcement; testing for end-use performance; developments in epoxide and polyurethane polymers. Further information and forms of application can be obtained from the Registrar, Bradford Institute of Technology, Bradford 7.

A Conference on "Recent Progress in Physical Optics" will be held in Paris during May 2-7, in association with the seventh general assembly of the International Commission for Optics. Further information can be obtained from the Secrétariat du Congrès CIO 7, Institut d'Optique, 3 Boulevard Pasteur, Paris 15. Funds have been made available for travel grants for: $(a)$ 'young scientists'; and (b) other scientific workers, to attend the conference. Applications for such grants should be made, before January 20, to the Chairman of the National Sub-committee for Optics, the Royal Society, Burlington House, London, W.1.

ADDENDUM. In the article entitled "Stimulation of the Uptake of Water and Ions by Indolyl-3-acetic Acid: its Dependence on Nucleic Acid and Protein Synthesis", by R. Mitra and S. P. Sen, which appeared on p. 861 of the August 21, 1965, issue of Nature, the explanations of the symbols used in the figures were omitted and are as follows:

Fig. 1. IAA; $O$, actinomycin $D$.

Fig. 2. O, IAA; $\triangle$, porphyromycin; $\bullet$, actinomycin $D$.

Fig. 3 . O, IAA; actinomycin $D$. 